\title{
MILITARIZAÇÃO DAS POLÍCIAS E DOUTRINA DE SEGURANÇA NACIONAL NO CONTEXTO DO COMBATE
} AO INIMIGO INTERNO NO BRASIL (1969-1970)

MILITARIZATION OF POLICIES AND NATIONAL SECURITY DOCTRINE IN THE CONTEXT OF COMBAT WITH INNER ENEMY IN BRAZIL (1969-1970)

\author{
Luís Eduardo Viana Fernandes* | Rafael Lamera Giesta CABral**
}

\section{RESUMO}

O presente estudo pretende analisar a influência da Doutrina de Segurança Nacional na militarização das polícias brasileiras entre 1969-1970. Durante a ditadura militar, houve desdobramentos na interpretação sobre quem é o "inimigo interno" para o Estado, o que poderia gerar impactos na militarização das polícias brasileiras. 0 modelo de militarização ocorrido na Força Pública do Estado de São Paulo passa a ser a referência central de análise nesse trabalho por ser um dos principais laboratórios práticos de institucionalização da Doutrina de Segurança Nacional no período em destaque. Para que os objetivos pudessem ser alcançados, a investigação histórico-jurídica debruçou-se sobre fontes primárias (documentos e relatórios produzidos na época) e secundárias (trabalhos acadêmicos e de doutrinas, em diálogo com as instituições e legislação). As modificações institucionais nas polícias militares desencadeadas pelos planejamentos e diretrizes de segurança interna do regime militar articularam-se às práticas dos agentes do Estado dentro de um aparato considerado autoritário, geridos exclusivamente pelas Forças Armadas, sem controle por parte das instituições e da população. A transição da ditadura para a democracia não foi capaz de ativar reformas institucionais na estrutura das políticas militares, sobretudo para a desmilitarização das polícias como forças auxiliares das Forças Armadas.

Palavras-chave: Polícia Militar. Doutrina de Segurança Nacional. Justiça de Transição.

\section{ABSTRACT}

This study aims to analyze the influence of the National Security Doctrine on the militarization of Brazilian police between 1969-1970. During the military dictatorship, there were developments in the interpretation of who is the "internal enemy" for the State. That interpretation could have impact on the militarization of Brazilian police. The São Paulo State Public Force militarization model became the central reference of analysis in this paper because it's one of the main practical laboratories for the institutionalization of the National Security Doctrine in the highlighted period. In order to achieve the objectives, the historical-legal investigation focused on primary sources (documents and reports produced at the time) and secondary sources (academic and doctrinal works, in dialogue with institutions and legislation). The institutional changes in the military police triggered by the military regime's internal security plans and guidelines were linked to the practices of State agents within an apparatus considered authoritarian, managed exclusively by the Armed Forces, without control by the institutions and the population. The transition from dictatorship to democracy has not been able to activate institutional reforms in the structure of military policies, especially for the demilitarization of the police as auxiliary forces of the Armed Forces.

Keywords: Military Police. National Security Doctrine. Transitional Justice.

* Pós-graduando lato sensu em Prática Judicial pela Universidade Federal do Rio Grande do Norte (UFRN). Graduado em Direito pela Universidade Federal Rural do Semi-Árido (UFERSA).

luiseduardo_viana@hotmail.com

** Doutor em Direito, Estado e Constituição pela Universidade de Brasília (UnB).

Coordenador do Programa de Mestrado em Direito da UFERSA. Editor-Chefe da Revista Jurídica da UFERSA. rafaelcabral@ufersa.edu.com 


\title{
SUMÁRIO
}

\author{
INTRODUÇÃO; 1 A DITADURA CIVIL-MILITAR E AS DIRETRIZES PARA O MODELO DE POLICIAMENTO \\ PAUTADO PELA DOUTRINA DE SEGURANÇA NACIONAL; 2 OPERAÇÕES DE SEGURANÇA INTERNA \\ EM SÃO PAULO: O MODUS OPERANDI DO POLICIAMENTO DE COMBATE AO INIMIGO INTERNO; \\ CONSIDERAÇÕES FINAIS; REFERÊNCIAS
}

\section{- INTRODUÇÃO}

O objetivo desta pesquisa foi resgatar o período em que se deram as principais modificações na organização das polícias militares entre 1969-1970, a fim de observar como se consolidou o desenvolvimento da lógica do inimigo interno ao mesmo tempo em que essas instituições ganharam a exclusividade do policiamento preventivo e repressivo.

A institucionalização da Doutrina de Segurança Nacional - DSN, como uma etapa complexa para o combate às supostas infiltrações comunistas no país (no contexto Guerra Fria), exigiu da ditadura civil-militar uma reorganização das forças auxiliares, como as polícias militares e polícias civis. Considerando a competência dos Estados para organizarem as suas respectivas estruturas de policiamento, nosso recorte espacial ficou circunscrito à experiência do Estado de São Paulo por três razões: primeiro, pelo fato de que foi ali que se concentrou a maior parte da luta armada contra a ditadura no período analisado e, segundo, porque a Força Pública de São Paulo, milícia adestrada nos moldes de um exército, serve como parâmetro para abordar a colocação das polícias militarizadas para o combate ao inimigo interno e, terceiro, por ter ocorrido nesse Estado, em 1969, a instalação da "Operação Bandeirantes", centro de tortura que foi o laboratório dos Destacamentos de Operações de Informações Centro de Operações de Defesa Interna (DOI-CODI) futuramente espalhados pelo Brasil.

O presente estudo desenvolver-se-á, principalmente, pelo método indutivo sobre as fontes documentais colhidas. Ademais, para nortear a investigação do tipo histórico-jurídico sobre as polícias militares, a pesquisa também exige um raciocínio dialético, dentro de uma lógica de conflito, uma vez que a abordagem feita aqui está na seara da história das instituições.

O trabalho utilizará como procedimento a pesquisa bibliográfica e documental sobre fontes diretas e indiretas, investigando textos de lei, documentos oficiais, ao mesmo tempo em que analisa artigos, livros, matérias jornalísticas, dossiês, relatórios e boletins informativos dos órgãos estatais sobre as polícias militares e a repressão estatal à subversão.

Num primeiro momento, o presente estudo abordará a consolidação do modelo de segurança implementado entre os anos de 1969-1970, focando no exacerbamento da militarização das polícias militares, com destaque para a questão da atuação policial no contexto de "guerra revolucionária comunista", principalmente pelas documentações secretas sobre segurança interna. Já na segunda parte, será tratado o desenrolar das operações de segurança interna especificamente no estado de São Paulo, sendo destacada a Operação Bandeirantes. 


\section{A DITADURA CIVIL-MILITAR E AS DIRETRIZES PARA O MODELO DE POLICIAMENTO PAUTADO PELA DOUTRINA DE SEGURANÇA NACIONAL}

Durante a Guerra Fria (1947-1991) "o mundo [esteve] dividido em dois campos: Ocidente e comunismo" ${ }^{1}$, o que se chamou de "bipolaridade". Como uma das marcas desse período, tivemos a instauração de diversas ditaduras da América Latina, sobretudo no Brasil, que viveu sob um regime autoritário de 1964 a 1985.

Na visão de Joseph Comblin a responsabilidade pela preparação do regime militar brasileiro é atribuída à Escola Superior de Guerra - ESG, instituição criada em 1949 como imitação da National War College de Washington. O padre belga associa a motivação dos militares brasileiros em instituírem uma escola nesses moldes devido à aproximação entre Brasil e Estados Unidos durante a Segunda Guerra Mundial, oportunidade em que os brasileiros teriam ficado surpreendidos com a superioridade dos norte-americanos, que, por sua vez, auxiliaram na fundação e orientação da ESG durante 12 anos através de uma missão militar. $^{2}$

Fábio Konder Comparato denominou de "mimetismo institucional" a criação de órgãos voltados à segurança nacional de modo semelhante aos Estados Unidos pelos demais países da América Latina, dentre eles, o Brasil. O autor também notou que o poder presidencial nestes "Estados de Segurança Nacional" estava comumente associado ao tripé do Conselho Nacional de Segurança - CNS, Sistema Nacional de Informações - SNI e Estado Maior das Forças Armadas - EMFA, sendo que, "[e]m todos eles, criaram-se, mesmo antes da tomada do poder pelos militares, Escolas Superiores de Guerra nos moldes do National War College, de Washington". ${ }^{3}$

Os teóricos da segurança nacional no Brasil desenvolveram e difundiram várias de suas ideias na ESG, dentre eles, podemos destacar o General Golbery Couto e Silva, um dos mais influentes formuladores da Doutrina da Segurança Nacional - DSN no subcontinente latino, para quem a guerra contra o comunismo seria "uma guerra pela sobrevivência do Ocidente", portanto, "uma guerra absoluta". ${ }^{4}$

Essa perspectiva traduz a ideia de "Guerra Total", no sentido de que o inimigo comunista, hábil e cada vez mais difundido em todos os âmbitos da sociedade a partir de uma nova técnica que seria a "Guerra Revolucionária", e "disseminada" pela União Soviética, "intentaria obter o controle da população pelo terror". ${ }^{5}$ Assim:

[...] o contra-terrorismo, defendia a Doutrina, deveria empreender o mesmo caminho para neutralizar a ação dos comunistas. Simultaneamente, exerceria o controle necessário para atingir o que na DSN denominava-se por ‘Objetivos

\footnotetext{
${ }^{1}$ COMBLIN, Pe. J. A Ideologia da Segurança Nacional: O Poder Militar na América Latina. Tradução A. Veiga Fialho. Rio de Janeiro: Civilização Brasileira, 1978. p. 30.

${ }^{2}$ Ibid. p. 155 e ss.

${ }^{3}$ COMPARATO, Fábio Konder. Segurança Nacional. Novos Estudos, Cebrap, São Paulo, v.1, 1, p. 51-57, dez. 1981. p. 56.

${ }^{4}$ GOLBERY, 1967 apud COMBLIN, Pe. J. Op. cit., p. 38.

${ }^{5}$ MENDES, Ricardo Antônio Souza. Ditaduras civil-militares no Cone Sul e a Doutrina de Segurança Nacional algumas considerações sobre a Historiografia. Revista Tempo e Argumento, Florianópolis, v. 5, n.10, jul./dez. 2013, p. 15.
} 
Nacionais'. Como etapas desse processo contrarrevolucionário colocavam-se, de forma sequencial, a identificação e eliminação dos simpatizantes do comunismo, a detecção dos membros da subversão e, por último, o extermínio desse núcleo central da oposição subversiva. Tudo isso acompanhado pelo desenvolvimento de ações cívicas que buscariam retirar a população da órbita de influência comunista. Para todas essas etapas era de extrema importância o trabalho de inteligência e informação, ainda que com a utilização da tortura. ${ }^{6}$

A disseminação do medo dessa suposta guerra eliminaria qualquer "diferença entre subversão, crítica, oposição política, guerrilha, terrorismo [e] guerra, já que tudo isso [era] manifestação de um único fenômeno, a guerra revolucionária". ${ }^{7}$

Para Comblin, ante a indefinição que permeia este conceito, é mais válido para a compreensão do que seria a "segurança nacional" ocupar-se em saber não o que se está defendendo, mas contra quem se defende, que seria o comunismo, o qual podendo estar em todos os lugares, determinaria a extensão da segurança nacional de igual modo. Dessa forma, "[a] segurança nacional afeta todos os aspectos da vida social. Em toda parte pode ser desafiada por ameaças: em toda parte, a subversão, sua grande inimiga, pode se manifestar". ${ }^{8}$ Portanto, a responsabilidade pela manutenção da segurança recaía sobre todos. ${ }^{9}$

Assim, a necessidade de se combater um inimigo infiltrado nas mais diversas camadas sociais, sob uma perspectiva de guerra permanente, levaria à "incorporação da segurança pública à segurança nacional" ${ }^{10}$, em que as Forças Armadas passam a ter a responsabilidade pela segurança interna ${ }^{11}$, além da já típica atribuição de defesa externa.

É na busca de eliminar esse inimigo interno que se realizam mudanças nas funções das milícias estaduais durante o regime militar.

Ainda em fevereiro de 1969, no âmbito do Ministério da Aeronáutica, foi realizado o I Seminário de Segurança Interna, evento "que reuniu em Brasília os secretários de Segurança Pública" de diferentes Estados, "os comandantes das polícias militares e os superintendentes regionais da Polícia Federal", tudo "sob a coordenação do ministro da Justiça Luís Antônio da Gama e Silva e do Chefe da Inspetoria Geral das Polícias Militares Gen. Carlos de Meira Matos". ${ }^{12}$

\footnotetext{
${ }^{6}$ Ibid. p.15-16.

${ }^{7}$ COMBLIN, Pe. J. op. cit., p. 47.

8 Ibid. p. 57.

${ }^{9}$ Nesse sentido, conforme artigo 1.ำ da Lei de Segurança Nacional de 1967: "toda pessoa natural ou jurídica é responsável pela segurança nacional, nos limites definidos em lei".

${ }^{10}$ GUERRA, Maria Pia. Polícia e Ditadura: a arquitetura institucional da segurança pública de 1946 a 1988. Brasília: Ministério da Justiça e Cidadania, 2016, p. 14.


“[a] segurança nacional compreende, essencialmente, medidas destinadas à preservação da segurança externa e interna, inclusive a prevenção e repressão da guerra psicológica adversa e da guerra revolucionária ou subversiva." E acrescenta-se que "[a] segurança interna, integrada na segurança nacional, diz respeito às ameaças ou pressões antagônicas, de qualquer origem, forma ou natureza, que se manifestem ou produzam efeito no âmbito interno do país".

${ }^{12}$ GUERRA, Maria Pia. Op. cit., p. 21.
} 
A relatoria do Seminário coube ao jurista Hely Lopes Meirelles ${ }^{13}$, então Secretário de Segurança Pública de São Paulo, que elaborou um documento de "sugestões para a integração dos órgãos da segurança interna"14, no qual esta já era colocada como parte integrante segurança nacional.

As sugestões para integração dos órgãos da segurança interna, expostas no Seminário, levaram em conta a necessidade de integração na execução das ações em meio a uma divisão complexa das atribuições do que seriam os "órgãos diretamente interessados na segurança interna".

O esquema traçado compreendia os órgãos normativos e de coordenação (Ministério da Justiça, Estado Maior das Forças Armadas e Inspetoria Geral das Polícias Militares - IGPM); órgãos de assessoramento (Conselho de Segurança Nacional); órgãos de informações (SNI e Divisões de Segurança e Informações dos Ministérios etc.) e órgãos de execução e, nesse quadro, as polícias estaduais eram consideradas órgãos de execução ${ }^{15}$ por excelência ao lado da Polícia Federal, cuja incumbência estaria na "prevenção e repressão dos atentados à segurança interna". ${ }^{16}$

Consta da discussão que, "segundo a doutrina nacional corrente", haveria o "Planejamento de Segurança Interna em situação de Paz", este dividido em um "Plano Político de Segurança Interna" e "Plano Militar de Segurança Interna"17, os quais ficavam a cargo do Ministério da Justiça e do Estado Maior das Forças Armadas, respectivamente, sendo que o último regularia as ações militares necessárias para o atingimento dos objetivos do primeiro.

Considerando que o seminário "[visava] mais diretamente o policiamento civil]"18, o relator delimitou como objeto do seu estudo apenas as questões de competência do Ministério da Justiça, abstendo-se de tratar dos planos de ordem militar.

Um dos pontos frisados foi o papel importante do Ministério da Justiça na integração dos órgãos de segurança, pois, era o órgão normativo ${ }^{19}$ responsável pela construção do Plano Político de Segurança Interna, bem como de "dois documentos fundamentais para a

\footnotetext{
13 Para uma melhor compreensão da atuação de vários juristas brasileiros em favor do regime militar e da doutrina de segurança nacional, Cf. DAL RI Jr., Arno. O conceito de segurança nacional na doutrina jurídica brasileira: usos e representações do Estado Novo à Ditadura Militar brasileira (1935-1985). Revista de Direitos Fundamentais e Democracia, Curitiba, v. 14, n. 14, jul./dez. 2013. p. 525-543. No caso especifico de Hely Lopes, é possível verificar tal militância num texto do próprio autor, Cf. MEIRELLES, Hely Lopes. O PODER DE POLÍCIA, O DESENVOLVIMENTO E A SEGURANÇA NACIONAL. R. Dir. adm, Rio de Janeiro, 125, jul./set. 1976. p.1-14.

14 BRASIL. MINISTÉRIO DA AERONÁUTICA. 4a Zona Aérea. Seminário de Segurança Interna: sugestões para integração dos órgãos de segurança interna - Relator Hely Lopes Meirelles, 13 mar. 1969a. São Paulo: Ministério da Aeronáutica, 1969, p.2.

${ }^{15}$ Os Serviços Secretos das polícias civil (SS) e militar (S-2) também estavam previstos, sendo que, na qualidade de Órgãos de Informação (BRASIL. MINISTÉRIO DA AERONÁUTICA. 4ạ Zona Aérea. Seminário de Segurança Interna: sugestões para integração dos órgãos de segurança interna - Relator Hely Lopes Meirelles, 13 mar. 1969a. São Paulo: Ministério da Aeronáutica, 1969.p.2.).

16 Ibid., p.2.

17 Ibid., p.2.

18 Ibid., p.2.

${ }^{19}$ Figuravam ao lado do Ministério da Justiça, na condição de órgãos normativos e de coordenação, o Estado Maior das Forças Armadas - EMFA e a Inspetoria Geral das Polícias Militares - IGPM.
} 
segurança interna" que seriam "as Diretrizes Gerais de Planejamento - DGP e a Diretriz Particular de Planejamento para a Segurança Interna - DPP/SI". ${ }^{20}$

Basicamente, foram tratadas as formas de integração entre as diferentes polícias (federal, civil e militar), esclarecendo as suas competências, possibilidades de atuação conjunta - inclusive mediante convênios -, bem como foram especificadas as respectivas atribuições de acordo com o tipo de crime enfrentado, se comum, de ordem político-social, contra interesse da união ou não. ${ }^{21}$

Ao final do trabalho, foi oferecida minuta de Resolução Reservada da alçada do Ministério da Justiça que regulamentaria as "Operações de Segurança Interna"22; aliás, estas já vinham sendo utilizadas no Estado de São Paulo ${ }^{23}$. Até a realização do Seminário de Segurança Interna não havia registro de operações como a Operação Bandeirantes - Oban, maior exemplo de ação dessa natureza, cujo início se deu em julho de 1969.

Já em relação aos planos de natureza militar, através de resolução de Costa e Silva, em 14 de julho de 1969, foram baixadas as "Diretrizes para a Política de Segurança Interna", considerando:

\begin{abstract}
Que a Segurança Nacional visa a garantir o desenvolvimento do País e a proporcionar o bem estar e a tranquilidade do povo brasileiro; Que a intensificação dos atos de terrorismo, assaltos a bancos, ataques a sentinelas e agentes da Lei, furto de armamento e munições, inclusive em quartéis, bem caracteriza o processo subversivo da guerra revolucionária em evolução; Que, a persistir a evolução desse quadro, a consecução dos superiores objetivos da Revolução e da Nação Brasileira, poderá vir a ser prejudicada, sendo [imperativa] a neutralização do processo subversivo [...]. ${ }^{24}$
\end{abstract}

Conforme se extrai da resolução, um dos anseios era justamente o estabelecimento de uma "coordenação, de âmbito federal e em nível presidencial, do planejamento, da supervisão e do controle da execução das ações de [segurança interna], em todo o [território nacional]", as quais "[seriam] conduzidas diretamente pelo Presidente da República e [englobariam] os campos político, econômico, psicossocial e militar, visando, em particular, as Informações e as Operações militares e policiais". ${ }^{25}$ De fato, havia um destaque na figura do Presidente, pois, seria este o responsável pela determinação de medidas gerais de caráter preventivo ou repressivo, fossem elas permanentes ou temporárias. ${ }^{26}$

Restava claro que Costa e Silva arrogava para si a coordenação das operações de combate à infiltração comunista, dentre as quais estavam incluídas as operações policiais,

\footnotetext{
${ }^{20}$ BRASIL. MINISTÉRIO DA AERONÁUTICA. 4a Zona Aérea. Seminário de Segurança Interna: sugestões para integração dos órgãos de segurança interna - Relator Hely Lopes Meirelles, 13 mar. 1969a. São Paulo: Ministério da Aeronáutica, 1969, p. 7.

21 lbid.

22 Ibid., p. 6.

${ }^{23}$ FON, Antônio Carlos. Tortura: A história da repressão política no Brasil. Revisão Dina de Deus. São Paulo: Global Editora e Distribuidora Ltda., 1979. Impressão: Editora Parma Ltda, p.18.

${ }^{24}$ BRASIL. CONSELHO DE SEGURANÇA NACIONAL. Diretrizes para a Política de Segurança Interna, de 14 de julho de 1969. Brasília, DF: Conselho de Segurança Nacional, 14 jul. 1969d. p. 1-2.

${ }^{25}$ BRASIL. Op. cit., p. 2.

26 Ibid.
} 
assim, abria-se espaço para a constatação da existência de um alongamento da segunda cadeia que integrava a "dupla cadeia de comando" 27 para as polícias militares. Havia, portanto, no plano legal, desde a edição do DL 317/67, uma subordinação das milícias tanto às Secretarias de Segurança Pública quanto à Inspetoria Geral das Polícias Militares - IGPM, ao passo que, no plano secreto, a subordinação das polícias era alongada para o controle direto e pessoal do próprio Presidente, nas ditas "ações ou operações de segurança interna".

A divisão nos campos acima exposta é um fiel exemplo do alinhamento à ideia de Poder Nacional, que é divido nos poderes: militar, político, econômico e o psicossocial e, Joseph Comblin já ressaltava o viés totalitário deste conceito, pois, "[o] Poder reúne recursos naturais, trabalho, ciência, técnica, capital, exército, polícia, sujeição, controle, censura, lei, costumes autoridades, tudo isso justaposto para formar uma só capacidade de ação". ${ }^{28}$

Nesse sentido, umas das diretrizes para a política de segurança interna previa que:

$\mathrm{Na}$ aplicação dos meios de que dispõe o Governo para se antepor ao recrudescimento da Guerra Revolucionária, torna-se indispensável a integração de todos os [ó]rgãos responsáveis pela Segurança Interna, isto é: Forças Armadas; Ministério da Justiça, em particular o Departamento de Polícia Federal; [Serviço Nacional de Informações - SNI]; [Divisões de Segurança e Informações - DSI] dos Ministérios Civis; Órgãos de Segurança Pública e Polícias Militares. Aos Comandantes de Exércitos e Comandantes Militares da Amazônia e do Planalto, caberá a responsabilidade pelo planejamento, coordenado e integrado, e pela execução das operações contra-revolucionárias em seus Territórios de conformidade com as instruções que Ihes forem expedidas. Para execução dessas missões, contarão: a. A disposição: Unidades do Exército localizadas na área; Polícias Militares Estaduais; Outras Unidades do Exército, colocadas em Reforço; b. Em apoio - cooperando em íntima ligação: Forças Navais e Aéreas, localizadas na área: Órgãos da Polícia Federal; Órgãos de Segurança Pública Estaduais. ${ }^{29}$

Entre 17 e 18 de julho de 1969, Costa e Silva determinou a expedição de ofícios aos Ministros Militares, da Justiça, Serviço Nacional de Informações e aos Governadores de todos os entes da Federação, no caso destes últimos, conforme se denota do Aviso n.․141/69, de 18 de julho de 1969, direcionado ao Governador de São Paulo, os expedientes continham os seguintes encaminhamentos:

Em consequência da recente análise da conjuntura nacional, decidiu o Senhor Presidente da República intensificar as ações contra a Guerra Revolucionária [...]. No quadro das ações integradas contra a Guerra Revolucionária situamse os Órgãos de Segurança Pública Estaduais, em particular as Polícias Militares, cujo emprego, em tais circunstâncias, está definido no Decreto-lei n. 667, de 02 de julho de 1969. Encarece o Senhor Presidente da República ordens de Vossa Excelência no sentido de que a Secretaria de Segurança Pública e particularmente a Polícia Militar, estabeleçam e mantenham ligação

\footnotetext{
${ }^{27}$ A dupla cadeia de comando consistia da subordinação das polícias militares tanto à IGPM quanto à Secretaria de Segurança do respectivo Estado (GUERRA, Maria Pia. Op. cit., p. 17).

${ }^{28}$ COMBLIN, Pe. J. Op. cit., p.58-59.

${ }^{29}$ BRASIL. CONSELHO DE SEGURANÇA NACIONAL. Diretrizes para a Política de Segurança Interna, de 14 de julho de 1969. Brasília, DF: Conselho de Segurança Nacional, 14 jul. 1969d, p. 3.
} 
com o Comando do... (Exército, Região Militar ou Guarnição Militar), para cumprimento das missões que lhes forem atribuídas. ${ }^{30}$

Sendo assim, resta claro que havia um papel para as polícias militares estaduais dentro do aparato estatal montado pela ditadura civil-militar para o combate ao comunismo, como foi lembrado no "aviso" encaminhado aos Estados. Àquela altura, já havia disposição para a atuação dos corpos armados de polícia na garantia da segurança interna, como também estava fixada a exclusividade do policiamento ostensivo pelas tradicionais milícias estaduais através do Decreto-lei no 667/69, de 02 de julho de 1969, como bem observou Guerra:

\begin{abstract}
A prerrogativa de policiamento nas ruas em contato direto com a população foi confiada em exclusividade às polícias fardadas, organizadas em hierarquia militar, sob controle das Forças Armadas. As dúvidas que porventura ainda existissem foram resolvidas pelo Decreto federal $\mathrm{n}$ - 1.072, de 30 de dezembro, que determinou a extinção das Guardas Civis e a incorporação aos quadros das polícias militares em até 180 dias. O Decreto federal no 667/69, como parte do processo de federalização, reforçou a militarização das polícias. Confirmou o foro especial previsto no Código Penal Militar e no Código de Processo Penal Militar para crimes de agentes das polícias militares (Decreto-lei federal no 1.001 e Decreto-lei federal no 1.002, de julho de 1969). Policiais Militares que cometessem crimes contra civis em exercício de função seriam julgados e responsabilizados não por cortes civis, mas por cortes especiais militares. ${ }^{31}$
\end{abstract}

Pouco tempo depois das primeiras diretrizes, Costa e Silva já propunha modificações no esquema da repressão ao comunismo e, assim, houve um aperfeiçoamento dos planejamentos de segurança interna, situação que somente veio a ser consolidada com a edição da Diretriz de Segurança Interna, de 17 de março de 1970, a qual, dentro de um "Sistema de Segurança Interna", previa uma Comissão de Alto Nível para assessoramento do Presidente em questões desta natureza, com a incumbência de fixar as responsabilidades de planejamento e execução das medidas contenção do avanço comunista. ${ }^{32}$ Observe-se, que permanecia a figura central do Presidente na participação direta nas ações de combate à ação subversiva, conforme já se tinha constatado Estudo Sucinto n.o 06/SG-01/70, de 02, de fevereiro de $1970 .^{33}$

Em decorrência dessa nova diretriz foi aprovado mediante resolução assinada por Médici, em 29 de outubro de $1970^{34}$, o Planejamento de Segurança Interna proposto pela Comissão de Alto Nível.

O referido planejamento é estruturado com uma exposição inicial no seu item " $A$ " da "Estratégia Adversa", que basicamente é o que o governo militar supunha ser a atuação de certos grupos em movimentação de guerra revolucionária. Na sequência, o item "B" previa a

\footnotetext{
${ }^{30}$ AVISO n.o 141/69, de 18 de julho de 1969. Brasília, DF, 18 jul. 1969.

${ }^{31}$ GUERRA, Maria Pia. Op. cit., p. 19.

32 BRASIL. CONSELHO DE SEGURANÇA NACIONAL. Diretriz de Segurança Interna, de 17 de março de 1970. Brasília, DF: Conselho de Segurança Nacional, 17 mar. 1970d.

${ }^{33}$ ESTUDO Sucinto n. 06 SG-01/70, de 02 de fevereiro de 1970. Brasília, DF, 02 fev. 1970. p. 9.

${ }^{34}$ BRASIL. CONSELHO DE SEGURANÇA NACIONAL. Resolução, de 29 de outubro de 1970. Brasília, DF: Conselho de Segurança Nacional, 29 out. 1970g.
} 
"Estratégia Geral do Governo" contendo as medidas de combate ao comunismo nos moldes da doutrina de segurança nacional. ${ }^{35}$

Por sua vez, no item " $\mathrm{C}$ " é que se começa a tratar do planejamento em si, com as "Bases Gerais do Planejamento", seguindo-se com a definição da "Responsabilidade e Planejamento de Execução" das medidas necessárias ao enfrentamento do comunismo no item "D". Por fim, as "Prescrições Diversas", no item "E", tratavam simplesmente dos prazos para elaboração dos planejamentos específicos de cada órgão, os quais deveriam ser entregues à Comissão de Alto Nível para apreciação. ${ }^{36}$

Debruçando-se especificamente sobre o item " $A$ ", verifica-se uma compreensão de que "facções minoritárias, em franca atividade de Guerra Revolucionária, submetidas à ação onipresente do Movimento Comunista Internacional, [procuravam] conturbar a vida nacional, particularmente através de atos de terrorismo assaltos e sequestros"; a estas facções estariam associados políticos cassados, membros "progressistas do clero"37, os quais atuariam em auxílio aos primeiros, seja na divulgação de uma desmoralização da ditadura civil-militar no cenário internacional, ou na dedicação à "conscientização dos jovens, das massas urbanas e rurais [...] visando orientá-los [...] à derrubada do Governo Federal e à mudança do regime, admitindo para isso, como válidos, inclusive a violência e a luta armada". ${ }^{38}$

Em resposta, o item " $\mathrm{B}$ " dispunha sobre a "Estratégia do Governo" para enfrentar a situação, em cujos objetivos fundamentais estariam:

a) Assegurar os ideais que norteiam a Revolução Brasileira, de Março de 1964; b) Preservar a população da ação do comunismo e mobilizá-la contra suas investidas; c) Garantir a plena consecução da Política de Desenvolvimento Nacional e; d) Aperfeiçoar o dispositivo de garantia da Segurança Interna. ${ }^{39}$

A ideia de Poder Nacional é operacionalizada nas diretrizes básicas através da previsão de um "Sistema de Segurança Interna", constituído por "[t]odos os órgãos da administração pública nacional, com responsabilidade direta ou indireta da Segurança Interna". ${ }^{40}$ Tal sistema mantinha a centralização o comando na pessoa do presidente, o qual "[o acionaria] diretamente [...], assessorado pela Comissão de Alto Nível, principalmente para coordenar e centralizar ações". ${ }^{41}$

Também é possível observar demasiada atenção com as ações preventivas, que deveriam ser tomadas de forma permanente e com prioridade para as "áreas-problema" que seriam as áreas "estudantil, magistério, trabalhista, clero, meios de divulgação de [massa]". ${ }^{42}$

\footnotetext{
35 BRASIL. CONSELHO DE SEGURANÇA NACIONAL. Op. cit, 1970.

${ }^{36}$ BRASIL. CONSELHO DE SEGURANÇA NACIONAL. Op. cit, 1970.

${ }^{37} \mathrm{~A}$ atuação de alguns setores da igreja foi muito significativa no tocante às denúncias de violações de direitos humanos pelo regime, nesse sentido, Cf. CARLOS, Juliana de Oliveira. A Anistia e a Luta pelos Direitos Humanos no Brasil. Cadernos AEL, v.13, n. 24/25, p. 169-205, 2008; Cf. ARQUIDIOCESE DE SÃO PAULO. BRASIL NUNCA MAIS. Prefácio Paulo Evaristo Arns. 3 ed. Petrópolis: Vozes, 1985.

${ }^{38}$ BRASIL. CONSELHO DE SEGURANÇA NACIONAL. op. cit., p. 1.

39 Ibid., p.2.

40 lbid., p.7.

41 Ibid., p.8.

${ }^{42}$ BRASIL. Conselho de Segurança Nacional. Op. cit., p.4.
} 
Por sua vez, "[a]s ações repressivas [deveriam] eminentemente episódicas, mas desencadeadas de maneira a assegurar os efeitos decisivos". ${ }^{43}$

Do mesmo modo, também é interessante a previsão no planejamento de Segurança Interna, no sentido de que:

\begin{abstract}
A fim de possibilitar um desengajamento progressivo das Forças Armadas daquelas ações tipicamente policiais, o Governo Federal e os Estados adotarão medidas que visem, respectivamente, ao fortalecimento do Departamento de Polícia Federal e dos Órgãos de Segurança Pública estaduais, compatibilizando-os com as missões que lhes incumbem face à realidade nacional. [...] A garantia da segurança interna deve ser alcançada pela aplicação do poder nacional, sob todas as suas formas ou expressões, de maneira sistemática, permanente e gradual, abrangendo, desde as ações preventivas até o emprego preponderante da sua expressão militar. ${ }^{44}$
\end{abstract}

Uma das formas de se alcançar tal objetivo seria através da formulação pelos Estados de seus próprios Planos de Segurança Interna, que, além da concordância com Estratégia Geral, deveriam ter "íntima ligação com os comandos militares com jurisdição sobre a área". 45 Ademais, para as ações integradas de segurança interna, seus estudos e coordenação, os Comandantes Militares teriam que contar com a assessoria da Marinha, Aeronáutica, Secretarias de Segurança Pública e as polícias civis e militares estaduais, da Polícia Federal, além de outras autoridades civis ou militares que julgasse necessário. ${ }^{46}$

O acima exposto carrega um viés burocratizado que dificilmente pode ser compreendido fora do contexto norteado pela DSN. Em síntese, tratava de um planejamento com ações de guerra num momento em que não havia sua declaração formal, uma estratégia secreta com distribuição de papéis bem definidos entre os órgãos estatais para o emprego da violência, na qual estavam inseridas as polícias militares estaduais no intuito da eliminação do inimigo subversivo.

Mesmo reconhecendo que a ameaça comunista advinha de facções minoritárias, a ditadura civil-militar brasileira não hesitou em montar uma aparelhagem literalmente de guerra para enfrentar a guerra revolucionária difundida pelo movimento comunista internacional e, para tanto, valeu-se, dentre outras medidas, da colocação de uma força militar para a realização do policiamento de rua.

Constatar que as polícias militares estariam envolvidas em planos voltados para guerra, por si só, não implicaria em qualquer novidade, haja vista que desde antes do regime militar, os corpos armados de polícia ostentavam a condição de forças auxiliares e reservas do Exército, portanto, em caso de eventual guerra externa, seria lógico que a mobilização das milícias estaduais precederia a do restante da reserva.

No entanto, é importante destacar que os planejamentos aqui expostos não abordam hipóteses de Guerra Clássica Convencional, a qual, nos termos da doutrina básica da ESG é: "[...] externa e entre estados; [...] declarada; [...] reconhecida pelos organismos internacionais

\footnotetext{
43 Ibid., p.4.

44 Ibid., p.4.

45 Ibid., p.6.

${ }^{46}$ BRASIL. Escola Superior de Guerra. Doutrina Básica. Rio de Janeiro: Imprimiu Gráfica e Editora Ltda., 1979.
} 
e; utiliza, em princípio, a plena capacidade das forças militares". ${ }^{47} \mathrm{O}$ caso tratado nos planejamentos militares acima expostos é de Guerra Revolucionária, caracterizada como "o conflito, normalmente interno, estimulado ou auxiliado do exterior, inspirado geralmente em uma ideologia, e que visa à conquista do poder pelo controle progressivo da nação". ${ }^{48}$

Os textos esguianos consideram a Guerra Revolucionária Comunista - GRC nos seguintes termos:

A concepção comunista da guerra, de acordo com Lenine, difere fundamentalmente da ocidental: 'A paz é a continuação da guerra por outros meios e deve ser tratada como um todo'. E ainda: 'A paz e a guerra não são senão dois aspectos da mesma luta, permanente e necessária.' Finalmente, lançando as bases para o surgimento de algo novo, afirma: 'Guerra e revolução são termos intermutáveis'. ${ }^{49}$

Nos marcos da DSN, a Guerra Revolucionária Comunista - GRC ${ }^{50}$ era abordada sob uma perspectiva de processo subversivo, de caráter permanente, conforme os termos usados pelo próprio Costa e Silva, na análise da conjuntura de intensificação da luta armada em São Paulo a partir de 1968, quando o Presidente militar entendia que a situação "bem [caracterizava] o processo subversivo da guerra revolucionária em evolução". ${ }^{51} \mathrm{~A}$ doutrina da ESG ensinava que "o desenvolvimento da GRC pode [...] ser descrito como a integração do processo subversivo nos estágios iniciais com a violência no estágio final, sendo esta última, em alguns casos, desnecessária, se o objetivo final já tiver sido atingido". ${ }^{52}$

Entretanto, o enfrentamento de tal processo subversivo ocorreria no campo da defesa interna e envolveria todas as medidas que visassem evitar, impedir, eliminar os dirigentes, destruir os mecanismos o processo e, ao fim, garantir a segurança interna. As atitudes e medidas eventualmente empregadas seriam de natureza preventiva, repressiva e/ou operativa, que também respeitariam uma escala gradual, conforme o avanço do processo subversivo. ${ }^{53}$

Já no momento das atitudes preventivas havia o anseio de se combater as "infrações contra a segurança nacional" e, genericamente, nessa categoria estariam enquadradas situações que em períodos não autoritários seriam nada mais do que o exercício regular de direitos pelos cidadãos a exemplo do direito de reunião. Do mesmo modo, a ação policial seria tomada numa perspectiva de "destruição de pequenos focos de agitação [e] controle e

\footnotetext{
${ }^{47}$ BRASIL. Op. cit., 1979, p. 207.

${ }^{48}$ Ibid., p. 209. De modo semelhante, o art. 3.ํ, § 3.ํ, do DL 898/69 dispunha que: “[a] guerra revolucionária é o conflito interno, geralmente inspirado em uma ideologia, ou auxiliado do exterior, que visa à conquista subversiva do poder pelo controle progressivo da Nação".

49 Ibid., p. 218.

${ }^{50}$ Para uma melhor compreensão sobre a ideia de Guerra Revolucionária Comunista, Cf. BRASIL. Escola Superior de Guerra. Doutrina Básica. Rio de Janeiro: Imprimiu Gráfica e Editora Ltda., 1979. 352 p. il. 21 cm. p. 215 e ss.

${ }^{51}$ BRASIL. CONSELHO DE SEGURANÇA NACIONAL. Diretrizes para a Política de Segurança Interna, de 14 de julho de 1969. Brasília, DF: Conselho de Segurança Nacional, 14 jul. 1969d. p.1.

${ }^{52}$ BRASIL. Escola Superior de Guerra. Doutrina Básica. Rio de Janeiro: Imprimiu Gráfica e Editora Ltda., 1979. 352 p. il. $21 \mathrm{~cm}$, p. 220.

${ }^{53}$ Ibid.
} 
eliminação de atos iniciais de perturbação da ordem pública". ${ }^{54}$ A competência para atuação nesses casos não seria de outra corporação que não a polícia militar.

Se a utilização dos corpos armados de polícia pelos governos estaduais estava voltada, historicamente, para a contenção de atos de perturbação da ordem ${ }^{55}$, entretanto, não é possível concluir que essa atuação se desse numa perspectiva de guerra como passou a ocorrer dentro dos marcos da doutrina de segurança nacional. Não é o caso de afirmar que se inaugurou a repressão policial contra manifestações de rua, greves etc., mas, que a ótica da guerra revolucionária como algo permanente e iniciada desde pequenos atos, implicou no direcionamento da violência estatal contra condutas das mais corriqueiras da vida social democrática, e que agora deveriam ser pulverizadas pela força policial.

Seguindo na análise das medidas a serem tomadas contra o processo subversivo, caso este não fosse contido em suas fases embrionárias, o Estado lançaria mão da atitude repressiva propriamente dita, uma espécie de intervenção mais incisiva, podendo envolver como forma de expressão política a decretação do estado de sítio, intervenção federal e restrições de liberdades de reuniões e, no campo da expressão militar, estariam o controle e eliminação agitações políticas e de focos de guerrilha, em ações de natureza militar de diferentes proporções. ${ }^{56}$

Enfim, ultrapassadas as primeiras etapas da guerra revolucionária e não tendo as atitudes preventivas e repressivas surtido efeito, seria necessário recorrer à etapa final da "atitude operativa", apresentada da seguinte forma:

Agora, embora se trate de luta entre nacionais, tem-se a certeza de identificação do elemento a eliminar; isto far-se-á através da destruição do mecanismo da ação subversiva e da neutralização de seus dirigentes. A situação a enfrentar é, portanto, a de Luta Interna, que se inclui numa das últimas etapas da Guerra Revolucionária. Ela abrange todas as formas de conflito armado, no interior do País, de caráter regular ou não, visando tanto a enfrentar interesses de um grupo ou de parcela da população, como objetivos colimados por outra nação ou coligação de nações. Envolve ações de luta armada, no campo ou na cidade, como as guerrilhas, os golpes de mão e até o choque de forças regulares rebeldes. A ação de ordem operativa é, pois, um desdobramento de operações típicas de guerra sem que se faça necessária a definição do 'status' bélico-jurídico. A situação de fato é que impõe a plena aplicação violenta do Poder, ainda no quadro restrito da Segurança Interna, sem dar ao contendor a caracterização de beligerante para evitar a aplicação dos princípios jurídicos internacionais. Todavia, malgrado a intenção de não tratar os problemas da Segurança Interna, por mais graves que sejam, como guerra, a hipótese de guerra - Guerra Revolucionária - pode configurar-se independente da vontade nacional. ${ }^{57}$

\footnotetext{
${ }^{54}$ Ibid., p.244-245.

${ }^{55}$ PINHEIRO, Paulo Sérgio. Polícia e Crise Política: o caso das polícias militares. In: BENEVIDES, Maria Vitoria et al. A Violência Brasileira. São Paulo: Brasiliense, 1982.

${ }^{56}$ BRASIL. Escola Superior de Guerra. Doutrina Básica. Rio de Janeiro: Imprimiu Gráfica e Editora Ltda., 1979. 352 p. il. $21 \mathrm{~cm}$.

${ }^{57}$ ASPECTOS Doutrinários. [S.I.: s.n.], [ca. 1975], p. 5.
} 
Retornando o foco para as ações preventivas e repressivas, é salutar a observação de Guerra ${ }^{58}$ acerca do Regulamento Geral das Polícias Militares e Corpos de Bombeiros, aprovado mediante o Decreto federal $n$. o 66862/70, o qual resultou em uma ampliação do campo de atuação das polícias ao mesmo tempo em que ampliou o controle destas pelo Exército. $A$ referida ampliação se deu pela definição de quais atividades estariam compreendidas nos conceitos de "perturbação da ordem" e "grave subversão da ordem", os quais estão previstos de forma genérica nos artigos 3.․, "a" e "b", do Decreto-lei n.․ 667/69, implicando na atribuição das milícias para atuarem em casos de:

[...] 14) Perturbação da Ordem - [que abrange] todos os tipos de ação, inclusive os decorrentes de calamidade pública que, por sua natureza, origem, amplitude e potencial possam vir a comprometer, na esfera estadual, o exercício dos poderes constituídos, o cumprimento das leis e a manutenção da ordem pública, ameaçando a população e propriedades públicas e privadas; a) Entre tais ações, destacam-se atividades subversivas, agitações, tumultos, distúrbios de toda ordem, devastações, saques, assaltos, roubos, sequestros, incêndios, depredações, destruições, sabotagem, terrorismo e ações de bandos armados nas guerrilhas rurais e urbanas; b) As medidas preventivas e repressivas neste caso, estão incluídas nas medidas de defesa interna e são conduzidas pelos Governos Estaduais, contando ou não com o apoio do Governo Federal; 15) Grave perturbação ou subversiva da Ordem Corresponde a todos os tipos de ação, inclusive as decorrentes de calamidade pública, que, por sua natureza, origem, amplitude, potencial e vulto: a) superem a capacidade de condução das medidas preventivas e repressivas tomadas pelos Governos Estaduais; b) sejam de natureza tal que, a critério do Governo Federal, possam vir a comprometer a integridade nacional, o livre funcionamento dos Poderes Constituídos, a Lei, a ordem e a prática das instituições; c) impliquem na realização de operações militares.

Assim, se por um lado esta ampliação de competências das milícias estava em concordância com as determinações do Planejamento de Segurança Interna, no sentido da substituição gradual das Forças Armadas nas ações tipicamente policiais pelos corpos armados de polícia dos Estados ${ }^{59}$, por outro, evidencia-se que o regime também considerava como solução o engajamento cada vez maior das organizações policiais em atividades essencialmente militares.

A manutenção da segurança interna, que motivou a fixação de exclusividade do policiamento preventivo e repressivo pelas polícias militares foi acompanhada, necessariamente, da responsabilidade de repressão dos crimes comuns, até mesmo porque "[i]ndependente do regime político, as atividades policiais de combate à criminalidade, patrulhamento, prestação de socorro, preservação da ordem, atendimento a demandas públicas continuam". ${ }^{60}$

\footnotetext{
${ }^{58}$ GUERRA, Maria Pia. Polícia e Ditadura: a arquitetura institucional da segurança pública de 1946 a 1988. Brasília: Ministério da Justiça e Cidadania, 2016. 152 p.

59 BRASIL. CONSELHO DE SEGURANÇA NACIONAL. Planejamento de Segurança Interna, de 29 de outubro de 1970. Brasília, DF: Conselho de Segurança Nacional, 29 out. $1970 f$.

${ }^{60}$ ROCHA, Alexandre Pereira da. A GRAMÁTICA DAS POLÍCIAS MILITARIZADAS: estudo comparado entre a Polícia Militar do Estado de São Paulo - Brasil e Carabineros - Chile, em regimes políticos autoritários e democráticos. 2013. 303f. (Doutorado em Ciências Sociais). Universidade de Brasília, p. 139.
} 
Veja-se que muito já se falou do papel das polícias militares no combate da guerra revolucionária, contudo, o inimigo em questão não estava definido na regulamentação legal sobre polícias, mas a sua identificação repousava na legislação penal de exceção.

De uma forma resumida, poderíamos dizer que paralelamente ao processo de federalização da segurança ${ }^{61}$ e a consequente ampliação do "escopo de atuação das polícias [militares]"62, ocorria um processo de ampliação do alcance e aperfeiçoamento da legislação penal de exceção ${ }^{63}$ voltada para condutas que seriam consideradas crimes contra a ordem política e social e a segurança nacional. Reforçando tal colocação, a ESG considerava que "[p]ara maior eficácia das ações de Segurança Interna é indispensável, no entanto, dar-Ihes apoio em legislação específica de Segurança Nacional". ${ }^{64}$

A Escola Superior de Guerra mencionava como instrumentos legais de Segurança Interna os seguintes diplomas:

\begin{abstract}
[A]lém dos dispositivos constantes da Constituição, convém destacar o Código Penal, a Lei de Segurança Nacional, a Lei do Serviço Militar, o DecretoLei da Reforma Administrativa [...], o Decreto-Lei da Reorganização das Polícias Militares e Corpos de Bombeiros [...], e o Decreto que define a estrutura do Departamento de Polícia Federal [...]. Finalmente, em outras leis ordinárias e em normas esparsas, gerais ou específicas, são considerados outros aspectos, como a definição de crimes de responsabilidades, o direito de reunião e de greve, as prescrições sobre a telecomunicação e os limites da liberdade de manifestação do pensamento e da informação ${ }^{65}$.
\end{abstract}

A Lei de Segurança Nacional - LSN, de 1969, prescrevia diversos tipos penais abertos, por exemplo, teríamos no art. 28, caput, do DL 898/69 as condutas de "[d] evastar, saquear, assaltar, roubar, sequestrar, incendiar, depredar ou praticar atentado pessoal, ato de massacre, sabotagem ou terrorismo", bem como no art. 27, caput, do DL 898/69, "[a]ssaltar, roubar ou depredar estabelecimento de crédito ou financiamento, qualquer que seja a sua motivação".

Tais exemplos de atos tipificados na LSN de 1969 evidenciam um alargamento exacerbado da lei penal especial, colocando em xeque até mesmo a atuação da simples divisão entre crime comum e a ofensa à segurança nacional, dado que tais condutas confundiam-se com boa parte das que já constavam na codificação penal comum. Tamanha vagueza e confusão na definição do que seriam atos de terrorismo, bem como a generalização de qualquer assalto de banco como ato subversivo, abre espaço para igual falta de clareza ao

\footnotetext{
${ }^{61}$ OLIVEIRA, Eliézer Rizzo de apud GUERRA, Maria Pia. Polícia e Ditadura: a arquitetura institucional da segurança pública de 1946 a 1988. Brasília: Ministério da Justiça e Cidadania, 2016.

${ }^{62}$ GUERRA, Maria Pia. Polícia e Ditadura: a arquitetura institucional da segurança pública de 1946 a 1988. Brasília: Ministério da Justiça e Cidadania, 2016. p. 20.

${ }^{63}$ Essa ampliação do alcance da legislação penal de exceção pode ser melhor compreendida através do prisma do duplo-nível de legalidade. Para tanto, Cf. MECCARELLI, Massimo. Regimes jurídicos de exceção e sistema penal: mudanças de paradigma entre Idade Moderna e Contemporânea. In: DAL RI Jr., Arno; SONTAG, Ricardo. História do Direito Penal entre medievo e modernidade. Belo Horizonte: Del Rey, 2011, p. 87 - 110.

${ }^{64}$ BRASIL. Escola Superior de Guerra. Doutrina Básica. Rio de Janeiro: Imprimiu Gráfica e Editora Ltda., 1979. p. 248.

65 Ibid., p. 249.
} 
policial sobre quais indivíduos seriam considerados literalmente como "inimigos" da guerra revolucionária.

\section{OPERAÇÕES DE SEGURANÇA INTERNA EM SÃO PAULO: O MODUS OPERANDI DO POLICIAMENTO DE COMBATE AO INIMIGO INTERNO}

Enquanto esteve à frente da pasta de segurança em São Paulo, Hely Lopes Meirelles informou que "[a] Polícia [vinha] se equipando, dia a dia, com novas viaturas e meios de comunicação, para o combate a subversão e ao terrorismo, formas novas de criminalidade para a qual não tinha sido preparada até então". ${ }^{66}$ Nesse sentido, observa-se que havia uma generalização da denominação dada àqueles que se enquadravam nos atos de guerrilha urbana em torno dos adjetivos de terrorista e subversivo.

Todavia, se admitirmos que a fixação da competência de policiamento exclusivo pelas polícias militares foi uma medida tendenciosa do regime em prol do combate à guerra revolucionária, não podemos de imediato afirmar que a simples modificação nesse plano surtiria os efeitos desejados pelos militares imediatamente.

Por um breve momento depois da entrada em vigor do Decreto-lei federal n.으 667/69, em relatório destinado ao Governador do Estado, Meirelles elogiava as ações da polícia civil, tanto no combate ao crime comum quanto ao terrorismo e, nesse sentido, apontava a ação de rondas noturnas como uma das medidas eficientes, o que, em tese, seria atribuição da Força Pública. Em contrapartida, o secretário informava que a milícia:

[...] não se [achava] preparada satisfatoriamente para a prevenção e repressão das novas modalidades criminais, notadamente os atentados violentos aos seus quartéis e os assaltos a Bancos, fases previstas da guerrilha urbana. Necessária [era] a reformulação da instrução e do sistema de policiamento adotado até então, pela Força Pública. ${ }^{67}$

Apesar de opinar pela ineficiência da Força Pública - FP no combate ao terrorismo, na mesma oportunidade, Meirelles apresentou as despesas com segurança nas quais a Força era responsável por mais de $50 \%$ dos gastos da pasta, cujo restante ainda seria dividido entre Polícia Civil e Guarda Civil. 68

Entre as ações terroristas relatadas por Meirelles estariam incêndios nas sedes das redes de televisão, bombas em cinemas, ataques às sentinelas das polícias, contudo, havia um problema que gerava maior preocupação ao secretário: justamente os assaltos aos bancos paulistas. ${ }^{69}$

\footnotetext{
${ }^{66}$ SÃO PAULO (Estado). Secretaria de Segurança Pública. Relatório Periódico Secreto n. o 17/69. São Paulo, 16 jul. 1969b, p.4.

${ }^{67}$ SÃO PAULO (Estado). Secretaria de Segurança Pública. Relatório Periódico Secreto n. 17/69. São Paulo, 16 jul. $1969 b$, p.5.

68 lbid.

69 Ibid.
} 
No ponto, considerou-se que em virtude da quantidade de agências bancárias em todo o estado, o policiamento realizado pela Força Pública era insuficiente, sobretudo pelo fato de que os assaltantes geralmente estarem em grupos de cinco ou mais, com ação comandada e portando armas automáticas. O foco da ação eram os grupos táticos armados incentivados pela Ala Marighella, Vanguarda Popular Revolucionária - VPR e Ala Vermelha. Enfatizou-se que "[t]ais assaltos, iniciados por grupos subversivos empenhados na obtenção de numerário para a sustentação da luta revolucionária visando a tomada do poder pela violência, já estão sendo imitados por marginais comuns [...]". ${ }^{70}$ Desse modo, havia uma percepção de que a luta armada literalmente estaria causando uma modificação nas ações criminosas de uma forma geral.

A preocupação com os atentados realizados nas agências bancárias requeria tanta atenção do secretário que o próprio chegou a oferecer minuta de Decreto-lei determinando que fosse "vedado o funcionamento de estabelecimento bancário sem dispositivo de segurança contra assaltos" 71 , algo bastante semelhante ao que viria a ser previsto no texto do Decreto-lei n. 1.034, de 21 de outubro de 1969.

O despreparo da Força Pública na tarefa de combate a subversão também era refletido na atividade de policiamento de rua. No SNI, a transferência da operação da rádiopatrulha pela FP era avaliada como desastrosa, sendo denunciado o alto índice de subnotificações às autoridades civis, situação esta que teria obrigado o DOPS a instalar uma rádio-escuta na faixa da rádio-patrulha a fim de serem interceptadas informações não repassadas pela Força Pública. ${ }^{72}$

Por outro lado, o referido despreparo não seria sentido por muito tempo no tocante ao enfrentamento da subversão, sobretudo após o início dos trabalhos da Operação Bandeirantes, desenvolvida pela ação conjunta "dos integrantes das Forças Armadas da área de São Paulo, e dos órgãos da Secretaria da Segurança Pública, e mais a Polícia Federal e o Serviço Nacional de Informações, para combate à subversão e ao terrorismo". ${ }^{73}$

Em reunião realizada no Quartel General do II Exército, no dia 24 de junho 1969, que o organizador do evento o General José Canavarro Pereira "[apresentou] a 'Operação Bandeirante', depois de historiada a luta contra a subversão e o terrorismo, e a omissão, o despreparo e a falta de entusiasmo de alguns órgãos no seu combate". ${ }^{74}$

O despreparo, que já era citado por Meirelles anteriormente acerca da Força Pública, foi lembrado pelo jurista com relação aos órgãos de segurança pública de uma forma geral em entrevista concedida ao jornalista Antônio Carlos Fon, quando ao ser perguntado sobre o terrorismo, respondeu que:

\footnotetext{
70 SÃO PAULO (Estado). Secretaria de Segurança Pública. [Representação sugerindo as providências necessárias à prevenção e repressão dos assaltos a Bancos]. São Paulo, 29 maio. 1969a. p.1.

${ }^{71}$ MEIRELLES, Hely Lopes. Minuta de Decreto-Lei: Dispõe sobre a segurança de estabelecimentos bancários e da outras providências. [S.I.: s.n.], [ca.1969], p.1.

72 BRASIL. SERVIÇO NACIONAL DE INFORMAÇÕES. Agência Central. Informação no 306/969/SNI/AC (Relatório) Assunto: FORÇA PÚBLICA DO ESTADO DE SÃO PAULO. Brasília: Serviço Nacional de Informações, 19 set. $1969 \mathrm{e}$.

${ }^{73}$ SÃO PAULO (Estado). Secretaria de Segurança Pública. Relatório Periódico Secreto n.o 17/69. São Paulo, 16 jul. 1969b, p.6.

${ }^{74}$ BRASIL. SERVIÇO NACIONAL DE INFORMAÇÕES. Agência Regional de São Paulo. Informação no 458/SNI/ASP/69

- Assunto: Operação Bandeirante. São Paulo: Serviço Nacional de Informações, 26 jun. 1969c.
} 


\begin{abstract}
Não havia nenhuma sistemática de repressão. Com a reiteração das ações subversivas, foi-se formando a técnica pela polícia, em cooperação com elementos de segurança das três forças armadas responsáveis pela manutenção da ordem na área e através de troca de informações de todos os serviços de segurança. ${ }^{75}$
\end{abstract}

A missão da Oban era "[i]dentificar, localizar e capturar os elementos integrantes dos grupos subversivos que atuam na área do II Ex., particularmente em São Paulo, com a finalidade de destruir ou pelo menos neutralizar as organizações a que pertençam" ${ }^{76}$

A fim de uma melhor organização, eram especificadas as atribuições dos órgãos pertencentes às Forças Armadas e os da Secretaria de Segurança do Estado em atividades de informações e operações, a primeira mais voltada para a coleta de informações e a segunda seriam as ações de caráter eminentemente policial, tudo isso dentro de um organograma com uma central de coordenação, outra de informações e mais uma de operações, ou seja, um esquema que guarda grande semelhança com o estabelecido no I Seminário de Segurança Interna realizado em fevereiro de 1969. ${ }^{77}$

Em virtude do caráter extralegal da Oban, foi definido o sigilo de todas as atividades, bem como fixada a diretriz de que:

\begin{abstract}
Em todas as operações - diligências para busca de informações, inclusive - os elementos delas participantes [deveriam] portar armamento individual e coletivo, capaz de fazer face a qualquer eventualidade. [Recomendava-se] o uso de granadas, metralhadoras portáteis e máscaras contra gases. [...] Todos os meios [seriam] válidos para levar a bom termo as missões e para salvaguardar a vida dos participantes das operações. ${ }^{78}$
\end{abstract}

Pelo exposto, imagina-se, de fato, um clima de guerra, sendo as ações dos grupos armados da esquerda deflagradas por assaltos e ataques aos soldados da Força Pública e Polícia Civil, portanto, ações rápidas, pontuais e imprevisíveis pelas milícias separadamente, fator que asseverava o "despreparo" da FP de forma isolada, conforme já foi destacado, daí a importância da integração com os demais órgãos. ${ }^{79}$

Dessa forma, nos termos do que foi informado por Meirelles, o combate ao inimigo subversivo se deu com maior força após a integração das atividades das Forças Armadas com as polícias militares, civil e federal e o SNI através da Oban. O recurso principal da operação não era outro senão a violência mediante torturas empregadas em suas dependências.

Tais métodos seriam oriundos, principalmente, das práticas já recorrentes dos agentes do Departamento de Ordem Política e Social - DOPS, de onde veio Sérgio Paranhos

\footnotetext{
${ }^{75}$ FON, Antônio Carlos. Tortura: A história da repressão política no Brasil. Revisão Dina de Deus. São Paulo: Global Editora e Distribuidora Ltda., 1979. Impressão: Editora Parma Ltda, p. 24.

76 BRASIL. MINISTÉRIO DO EXÉRCITO. II Exército. Quartel General. OPERAÇÃO BANDEIRANTE. São Paulo: Ministério do Exército, 24 jun. 1969b. p.3.

77 Ibid.

78 Ibid., p.6.

${ }^{79}$ SÃO PAULO (Estado). Secretaria de Segurança Pública. Relatório Periódico Secreto n. 17/69. São Paulo, 16 jul. $1969 b$.
} 
Fleury, assim como da Divisão de Crimes Contra o Patrimônio. O referido delegado liderou diversas emboscadas contra guerrilheiros, a mais famosa delas, a que culminou com a morte de Marighella. Fleury acumulava as funções de combate à subversão ao tempo em que encabeçava o "Esquadrão da Morte", responsável pelas execuções sumárias de criminosos comuns em larga escala no período da ditadura civil-militar. ${ }^{80}$

A eficiência da operação em termos de tortura contra os investigados foi tamanha que serviu de modelo para a criação dos Destacamentos de Operação Interna - DOI e Centros de Operações e Defesa Interna - CODI. ${ }^{81}$

O andamento dos trabalhos da Oban e a sua reprodução da sua estrutura nos DOI CODI, ampliados para todo o Brasil, teria dado resultados consideráveis, inclusive, em 02 de dezembro de 1969, quando a Agência do SNI em São Paulo reproduziu um editorial da Revista Veja em que se veiculava um pronunciamento de Médici que:

[...] 'determinou aos órgãos responsáveis pela segurança pública e combate à subversão - [...] acusados de torturar presos políticos a até simples suspeitos depois inocentes - que [deveriam] rever imediatamente seus esquemas de repressão e por fim ao uso de métodos violentos' [...]. O presidente [achava] mesmo era que terroristas brasileiros chegaram a ser superestimados, pela importância com que suas ações isoladas - apesar de alguns lances sensacionais - foram recebidas pelas autoridades, mesmo assim, Garrastazú Médici [estava] sempre atento às possíveis manobras espetaculares dos terroristas, [...] e sabia que [precisava] da confiança geral que já começou a estimular quando propôs o seu 'jogo da verdade' - e também de um clima de liberdade em que a Justiça e os direitos civis sejam amplamente reconhecidos. Certo de que não enfrentará rebeliões nem contestações nas Forças Armadas, o presidente enfrenta a subversão com novos triunfos: além do combate policial-militar - até agora bem sucedido: a morte de Marighela é uma das provas -, o presidente quer lutar contra o terrorismo com uma maciça e entusiástica adesão popular ao seu governo. ${ }^{82}$

A real intenção das palavras de Médici, porém, devem ser analisadas com bastante cautela, visto que, são ao menos controversas, porquanto durante a sua gestão a repressão foi intensificada, bem como foi ele quem assinou a Diretriz de Segurança Interna, em 14 de março 1970, em cujo texto estava previsto o "Sistema de Segurança Interna", fixando o organograma da repressão utilizado na ditadura civil-militar.

Ademais, agência do SNI em São Paulo também tomou nota de um editorial de "O Estado de São Paulo", assinado pelo jornalista Evandro Carlos de Andrade, no qual a ideia de uma guerra revolucionária em curso no Brasil foi questionada de forma incisiva, chegando a afirmar que "o anúncio de que ainda em 1969 essa pretendida guerra revolucionária entraria

\footnotetext{
${ }^{80}$ SÃo PAULO (Estado). Assembleia Legislativa do Estado de São Paulo. Comissão da Verdade do Estado de São Paulo "Rubens Paiva". Estruturas e Sistemas da Repressão. In: Relatório. São Paulo: 2015. 648 p.

${ }^{81}$ FON, Antônio Carlos. Tortura: A história da repressão política no Brasil. Revisão Dina de Deus. São Paulo: Global Editora e Distribuidora Ltda., 1979. Impressão: Editora Parma Ltda.

82 VEJA apud BRASIL. SERVIÇO NACIONAL DE INFORMAÇÕES. Agência de São Paulo. BOLETIM INFORMATIVO NNo 280, de 02 de dezembro de 1969. São Paulo: Serviço Nacional de Informações, 02 dez. $1969 f$.
} 
na fase da guerrilha rural não se confirmou porque ele era tão falso quanto o é a própria suposta guerra revolucionária, que não existe no Brasil". ${ }^{83}$

Recordando as etapas da guerra revolucionária, o editorial ressaltou que situações capazes de evidenciar a guerra como a infiltração, propaganda e controle nos meios de comunicação e administração pública sempre existiram e, especialmente sobre a propaganda, esta se limitava à distribuição eventual de panfletos em alguns lugares esparsos - o que, por sinal, era tipificado como crime pelas leis de segurança nacional do regime. Citando o exemplo dos Estados Unidos, o jornalista informava que os atentados por lá eram bem piores do que os nossos, contudo, a Constituição Americana não havia sido alterada e não estavam os mesmos sob o alarde da guerra revolucionária. ${ }^{84}$

As manchetes em meados de janeiro de 1970 já davam conta de que havia uma diminuição das ações de guerrilha urbana, inclusive com a polícia selando o fim do terrorismo. ${ }^{85}$ Contudo, a impressão de que a luta armada tivesse cessado não durou muito, até que, em junho de 1970, o sequestro do embaixador alemão resultou numa operação com "[c]inco mil agentes, pertencentes ao SNI, [Centro de Informações da Marinha] - CENIMAR, Serviço de Informações do Exército e outros órgãos de segurança federais, bem como elementos das polícias estaduais, foram mobilizados na caça aos sequestradores". ${ }^{86}$

Portanto, havia a utilização de operações militares de grande proporção envolvendo as polícias, entretanto, contrariamente ao que se dispunha nos decretos e na doutrina básica da ESG, tais situações não exigiam o respeito à configuração das hipóteses de estado de sítio ou intervenção federal. Na verdade, movidas pelo calor da situação e, pautadas por planejamentos secretos, operações militares desse tipo ocorreriam sem maiores apegos aos ditames legais, afinal, a guerra era total e permanente e o fim da segurança nacional era absoluto.

Mantida ainda a política de reorganização do policiamento contra a subversão, em outubro de 1970, foi criada a Ronda Ostensiva Tobias de Aguiar - ROTA, com a incumbência de atuar em todo o território da grande São Paulo, "para combate aos terroristas e marginais e no caso de grandes ocorrências". ${ }^{87}$ Desde então, a instituição permanece atuando como a elite da polícia militar no Estado paulista, sendo que não foi este o único pelotão especializado criado para combate à subversão no período.

É também no ano de 1970 que, enfim, ocorre a unificação entre a Guarda Civil e a Força Pública formando então a Polícia Militar do Estado de São Paulo por meio do Decretolei estadual n. 217/1970, para tanto, os antigos integrantes da Guarda Civil tiveram que passar pelos estágios que incluíam o estudo da doutrina de segurança nacional, segurança interna e aplicação do código de processo penal militar às polícias. Ademais, a unificação favorecia a manutenção da organização nos moldes da antiga Força Pública, inclusive, mesmo

\footnotetext{
83 ANDRADE, 1970 apud BRASIL. SERVIÇO NACIONAL DE INFORMAÇÕES. Agência de São Paulo. BOLETIM INFORMATIVO No 27. São Paulo: Serviço Nacional de Informações, 02 fev. 1970c, p.6.

84 Ibid.

${ }^{85}$ BRASIL. SERVIÇO NACIONAL DE INFORMAÇÕES. Agência de São Paulo. BOLETIM INFORMATIVO No 12. São Paulo: Serviço Nacional de Informações, 15 jan. 1970a; BRASIL. SERVIÇO NACIONAL DE INFORMAÇÕES. Agência de São Paulo. BOLETIM INFORMATIVO NNo 24. São Paulo: Serviço Nacional de Informações, 29 jan. 1970b.

${ }^{86}$ BRASIL. SERVIÇO NACIONAL DE INFORMAÇÕES. Agência de São Paulo. BOLETIM INFORMATIVO NNo 142. São Paulo: Serviço Nacional de Informações, 18 jun. 1970e, p.5.

${ }^{87}$ GUERRA, Maria Pia. Op. cit., p.49.
} 
com a incorporação do pessoal da Guarda Civil, tornou-se uma corporação ainda mais militarizada. ${ }^{88}$

As antigas divergências entre as corporações também seriam levadas para dentro do quotidiano da nova polícia militar paulista, como pode ser extraído de um relatório do SNI, elaborado pela Agência Regional de São Paulo que dá conta de "[notórias] divergências internas nos quadros da PMESP [...]" e, num claro exemplo de que os antigos guardas civis seriam policiais militares de segunda classe, foi constatado que os praças da nova polícia corriqueiramente se referiam aos oficiais da antiga FP como "oficiais quentes" e, aos da extinta Guarda Civil, como "oficiais frios". ${ }^{89}$

A unificação de algum modo também teria impacto sobre a Polícia Civil, se por um lado os delegados já haviam perdido atribuições de controle das ações de policiamento com a Lei Orgânica das Polícias de 1968, agora eram obrigados a ver a formação de uma corporação gigantesca que era a Polícia Militar de São Paulo consumindo, sozinha, $74 \%$ do orçamento da Secretaria de Segurança Pública de São Paulo, enquanto a polícia civil respondia somente por $21 \%$ dos gastos. ${ }^{90}$

No Estado de São Paulo ainda ocorreriam outras modificações legislativas que atingiriam as polícias militares, dentre elas, a aprovação da Lei estadual no 616, em 1974, reorganizando as polícias militares e, até o final da ditadura, no plano federal, parte da regulamentação seria alterada como uma das medidas de uma leve descentralização realizada pelos militares um pouco antes da posse dos governadores eleitos democraticamente em 1982, como exemplo, a subordinação administrativa das polícias militares ao Governador retomadas com o Decreto-lei n. 2.010, de 12 de janeiro de $1983 .{ }^{91}$

Maria Pia Guerra92, a partir das conclusões de Alexandre Pereira da Rocha e Arthur Trindade Maranhão Costa, sintetiza que ambos reconhecem a hipermilitarização das polícias brasileiras durante a ditadura civil-militar, uma vez que, ao tempo em que foram aproximadas das Forças Armadas, instrumentalizadas pelo governo militar para o atendimento dos seus anseios norteados pela Doutrina de Segurança Nacional, houve uma autonomização das polícias em relação às demandas da sociedade civil por segurança. Em síntese, as polícias tornaram-se cada vez mais distantes da finalidade de atendimento ao cidadão.

Contudo, mais do que atentar para o fato de que boa parte da legislação elaborada no período de 1967-1970 sobre as polícias militares permanecer a mesma, o fato do seu chamamento para a prática de policiamento ostensivo de forma exclusiva, porquanto intimamente ligado ao combate à subversão numa ótica de inimigo terrorista ou subversivo a ser eliminado, destruído ou neutralizado, é algo nos remete às reflexões sobre a adequação da permanência desse modelo de polícia em nossos tempos. É justamente o paradoxo apontado por Muniz ${ }^{93}$ ao observar que as polícias militares retomaram a sua função de

\footnotetext{
${ }^{88}$ Ibid.

${ }^{89}$ BRASIL. MINISTÉRIO DO EXÉRCITO. II Exército. Quartel General. Relatório Periódico de Informações. São Paulo: Ministério do Exército, 18 jan. 1971, p.2.

${ }^{90}$ Associação dos Delegados de Política; Associação dos funcionários da Polícia Civil; Associação dos Escrivães de Polícia; Associação dos Pesquisadores Datiloscópicos e datiloscopistas; Associação dos Servidores do Serviço de Transportes Motorizados [O ataque gratuito aos delegados de polícia]. São Paulo: [s.n], 1970.

${ }^{91}$ GUERRA, Maria Pia. Op. cit, 2016.

${ }^{92}$ Ibid.

${ }^{93}$ MUNIZ, Jaqueline. A Crise de Identidade das Polícia Militares Brasileiras: Dilemas e Paradoxos da Formação Educacional. Security and Defense Studies Review, Vol. 1, Winter 2001. p. 177-198.
} 
policiamento ostensivo logo na época em que as suas atribuições militares foram mais requeridas.

Observamos, assim, que em um primeiro momento, a milícia paulista era avaliada como despreparada para o enfrentamento da subversão crescente no Estado de São Paulo, ou seja, faltava preparo para o emprego desmedido da violência em confronto com a guerrilha urbana. Contudo, a sua formação militar, pautada pela hierarquia, disciplina e instrução para o combate, tornava a Força Pública moldável aos interesses do regime, em verdade, e conforme já notado por Guerra ${ }^{94}$, essa organização sofreu uma maior militarização a fim de que cumprisse as diretrizes da Doutrina de Segurança Nacional. Eis que, confirmando o que já foi assinalado pela autora, não é o caráter militar de uma polícia que a torna violenta.

Por outro lado, devemos lembrar que a Doutrina de Segurança Nacional adotada pela ditadura civil-militar não inaugurou o estigma de inimigo sobre determinado grupo, pois, conforme as palavras de Angela de Castro Gomes:

\footnotetext{
Se em 1920 a questão social foi definida como uma questão policial — e os anarquistas foram apontados como o "inimigo objetivo" - em 1935 ela iria ser definida como uma questão de segurança nacional, e o mesmo tipo de discurso acusatório iria se voltar contra uma nova categoria: os comunistas. ${ }^{95}$
}

No mesmo sentido, a doutrina difundida pela Escola Superior de Guerra não inovou no tocante à criação de mecanismos jurisdicionais e policiais de repressão, veja-se que na Era Vargas foi instaurado o Tribunal de Segurança Nacional - TSN, bem como as Delegacias de Ordem Política e Social - DEOPS, no âmbito dos Estados, para a perseguição da subversão. ${ }^{96}$

A questão trazida aqui é o fato de que, em nenhum desses casos citados, estamos tratando da colocação de uma força repressiva já militarizada - qualidade aguçada gradativamente pelo regime - tão próxima da população, visando um enfrentamento de um inimigo onipresente numa "guerra revolucionária" total e permanente.

Mesmo que não seja possível afirmar, de imediato, que uma polícia por ser militarizada também seja violenta, não se pode olvidar que tenha sido incentivada a isso durante a ditadura civil-militar. Esse tipo de mudança do modus operandi só foi alcançado, gradativamente, através de um intenso controle pelos militares e, uma consequente perda de controle pela comunidade, no que se chamou de insulamento das polícias. ${ }^{97}$ Assim, a permanência da falta de controle cidadão sobre as polícias militares na atual ordem constitucional, prejudica em muito a mudança nos rumos para o atendimento ao cidadão e em prol de uma prática que preze pelos direitos humanos.

\footnotetext{
${ }^{94}$ GUERRA, Maria Pia. Op. cit., 2016.

${ }_{95}^{95}$ OMES, Angela de Castro. A invenção do trabalhismo. 3. ed. Rio de Janeiro: Editora FGV, 2005, p. 175.

${ }^{96}$ NUNES, Diego. O percurso dos crimes políticos durante a Era Vargas (1935-1945): do Direito Penal político italiano ao Direito da Segurança Nacional brasileiro. Dissertação (Mestrado em Direito). Florianópolis: UFSC, 2010 .

97 GUERRA, Maria Pia. Op. cit., 2016.
} 
Desse modo, quando se trata de uma busca por uma Justiça de Transição dentro das lições de Paul van $\left.Z y\right|^{98}$ de "[i]dentificação das instituições que devem ser reformadas ou eliminadas", compartilhamos da visão de que a continuidade de uma polícia instituída para o combate de um inimigo na ordem democrática não se adequa a prática que prime pela observância dos direitos humanos.

É nesse sentido que o amadurecimento da proposta de desmilitarização feita pela Comissão Nacional da Verdade - CNV demonstra ser uma medida necessária dentro de um dos seus pilares da Justiça de Transição que é o campo da Reforma das Instituições.

Portanto, as recomendações da CNV, que não prega o fim da polícia militar, mas sim, o fim da vinculação destas às Forças Armadas, com as medidas "constitucionais e legais que acarretem [...] a plena desmilitarização desses corpos policiais, com a perspectiva de sua unificação em cada estado" 99 , são de grande valia para que se possa dar efetividade a uma reforma institucional tão necessária para que se afaste essa parte do legado deixado pela ditadura civil-militar para os tempos democráticos, medida que se impõe para o alcance de uma Justiça de Transição efetiva. ${ }^{100}$

\section{- CONSIDERAÇÕES FINAIS}

A partir do golpe de 1964, notamos que o Estado de Segurança Nacional brasileiro busca montar um aparato repressivo a partir dos dogmas da DSN, a fim do enfrentamento da guerra revolucionária comunista.

Essa nova modalidade de guerra, preconizada entre nós pela Escola Superior de Guerra, diferentemente da guerra convencional externa entre os Estados, se configurava a partir de um processo subversivo interno, cujas fases envolviam desde os mais irrelevantes atos da vida cotidiana até o emprego da violência e terror. Portanto, no contexto de um estado de segurança nacional a guerra seria absoluta e permanente.

Se havia um arcabouço normativo em caráter de exceção sobre as polícias militares que por si já evidenciava a função policial em prol da segurança nacional, existia também a construção de um "Sistema de Segurança Interna" através de diretrizes e planejamentos, confeccionados secretamente pelo alto escalão do governo militar com o fim de combater a guerra revolucionária. No primeiro caso, encontramos uma dupla cadeia de comando das polícias militares subordinadas de forma permanente à Secretaria de Segurança Pública dos estados e à IGPM, já nos planos secretos do regime, este segundo nível de subordinação era

\footnotetext{
${ }^{98}$ VAN ZYL, Paul. Promovendo a justiça transicional em sociedades pós-conflito. Revista Anistia Política e Justiça de Transição, n. 1 (jan./jun. 2009). Brasília: Ministério da Justiça, 2009.

${ }^{99}$ BRASIL. Comissão Nacional da Verdade - CNV. Relatório da Comissão Nacional da Verdade: v. 1. Brasília: CNV, 2014, p. 971-972. Para maiores detalhes, ver OLIVEIRA, Ramon Rebouças Nolasco de; CABRAL, Rafael Lamera Giesta. Comissão Nacional da Verdade no Brasil: o fio do relato e o direito à memória e à verdade. Revista Culturas Jurídicas, Niterói, v. 6, n. 13, 2019; Ver ainda: MARQUES, R. de P. Julgar o passado? Verdade histórica e verdade judicial na ADPF 153. Revista Jurídica da UFERSA, Mossoró, v. 2, n. 3, 2018.

100 Para maiores detalhes, ver ainda GUERRA, Maria Pia. Reformas institucionais: contribuições da justiça de transição e do direito e desenvolvimento. Revista Jurídica da UFERSA, Mossoró, v. 3, n. 5, 2019.
} 
alargado para submissão direta das forças policiais e militares ao Presidente quando se tratassem das operações de segurança interna.

Foi também demonstrado que a Doutrina de Segurança Nacional ao quebrar uma tradicional concepção de guerra externa, trazendo-a para o plano interno, implicou na criação do "inimigo interno" dentro das fronteiras e entre os nacionais, cuja figura foi construída, paulatinamente, tanto na modificação da lei penal de exceção quanto na prática policial em torno das figuras do subversivo e terrorista. Do mesmo modo, essa ruptura vinculou a segurança pública ao campo da segurança interna.

A resposta dada pelo regime ao crescimento da guerrilha urbana, determinando a responsabilidade exclusiva pelo policiamento ostensivo para as antigas milícias estaduais, transformou estas na linha de frente do Estado na luta contra a guerra revolucionária, visto que buscavam retirar gradualmente as Forças Armadas das ações policiais e ampliavam o campo de atuação da polícia para operações de cunho militar.

Porém, estrutura da antiga Força Pública, adestrada nos moldes de um exército, organizada sob a hierarquia e disciplina, não implica num perfeito encaixe em termos de preparo imediato para os conflitos contra a guerrilha, tampouco significa uma predisposição para a violência, visto que, logo que houve a intensificação da luta armada contra o regime em São Paulo, a avaliação era de um total despreparo da milícia para a repressão do terrorismo. Tal preparação exigiu a intensificação contínua do controle sobre as polícias.

Se não podemos falar nesse encaixe perfeito, entretanto, podemos concluir que o caráter militar das polícias facilitava a sua adaptação para a nova função de enfrentamento da guerra revolucionária, já que, em verdade, os resultados contra o avanço da guerrilha urbana ocorreram, sobretudo, a partir da integração das Forças Armadas e policias estaduais civil e militar na "Operação Bandeirantes", que serviu de modelo para os DOI-CODI posteriormente espalhados pelo Brasil.

Por outro lado, as mortes dos principais líderes das guerrilhas urbana e rural e uma diminuição considerável da luta armada ainda no fim de 1969, não impediram que a polícia continuasse a ser militarizada, inclusive, com a criação de divisões e pelotões especializados no combate a subversão, a exemplo da ROTA que permanece em atividade até hoje.

Considerando que a repressão ao comunismo no Brasil não se inaugurou com a ditadura civil-militar de 1964-1985, nem foi esse o marco das modificações jurisdicionais e policiais nesse sentido, porém, em virtude da guerra revolucionária comunista, com o inimigo presente em todos os campos da vida social, o regime colocou uma força militarizada nas ruas, ou seja, mais próxima da população em caráter permanente, algo que não havia sido observado até então.

Diante do exposto, o caso das polícias militares no Brasil com a permanência da falta de controle pela população, ao tempo em que permanecem geridas pelo Exército, aponta para a necessidade de reforma, não com o seu fim, mas sim, nos termos do que foi proposto na recomendação no 20 da Comissão Nacional da Verdade, com a desvinculação destas da condição de reserva das Forças Armadas e a sua plena desmilitarização.

Desse modo, considerando que uma reforma das instituições pressupõe a avaliação das instituições que devem ser reformadas, compartilhamos da visão de que a continuidade 
de uma polícia instituída para o combate de um inimigo na ordem democrática não se adequa a prática que prime pela observância dos direitos humanos.

Assim, a fim de se promover uma Justiça de Transição efetiva, a proposta de desmilitarização feita pela CNV demonstra ser uma medida necessária dentro de um dos seus pilares que é o campo da Reforma das Instituições.

\section{REFERÊNCIAS}

ARQUIDIOCESE DE SÃO PAULO. Brasil nunca mais. Prefácio Paulo Evaristo Arns. 3 ed. Petrópolis: Editora Vozes Ltda, 1985.

ASPECTOS Doutrinários. [S.I.: s.n.], [ca. 1975]. Disponível em: http://imagem.sian.an.gov.br/br_dfanbsb_n8/0/agr/avu/0013/br_dfanbsb_n8_0_agr_avu_0 013_d0001de0001.pdf. Acesso em: 03 set. 2018.

ASSOCIAÇÃO DOS DELEGADOS DE POLÍCIA; ASSOCIAÇÃO DOS FUNCIONÁRIOS DA POLÍCIA CIVIL; ASSOCIAÇÃO DOS ESCRIVÃES DE POLÍCIA, ASSOCIAÇÃO DOS PESQUISADORES DATILOSCÓPICOS E DATILOSCOPISTAS; ASSOCIAÇÃO DOS SERVIDORES DO SERVIÇO DE TRANSPORTES MOTORIZADOS. [O ATAQUE GRATUITO. AOS DELEGADOS DE POLÍCIA]. São Paulo: [s.n], $1970 . \quad$ Disponível em: http://imagem.sian.an.gov.br/br_dfanbsb_1m/0/0/9592/br_dfanbsb_1m_0_0_9592_d0009 de0041.pdf. Acesso em: 03 set. 2018.

AVISO n.o 141/69, de 18 de julho de 1969. Brasília, DF, 18 jul. 1969. Disponível em: http://imagem.sian.an.gov.br/br_rjanrio_cnv/0/rce/00092000097201482_v_02/br_rjanrio_c nv_0_rce_00092000097201482_v_02_d0001de0001.pdf. Acesso em: 03 set. 2018.

BRASIL. Comissão Nacional da Verdade - CNV. Relatório da Comissão Nacional da Verdade: v. 1. Brasília: CNV, 2014. 976 p. ISBN 978-85-85142-64-3 (v. 1 digital). Disponível em: http://cnv.memoriasreveladas.gov.br/images/pdf/relatorio/volume_1_digital.pdf. Acesso em: 15 fev. 2018.

CONSELHO DE SEGURANÇA NACIONAL. Diretrizes para a Política de Segurança Interna, de 14 de julho de 1969. Brasília, DF: Conselho de Segurança Nacional, 14 jul. 1969d. Disponível

em: http://imagem.sian.an.gov.br/br_rjanrio_cnv/0/rce/00092000097201482_v_02/br_rjanrio_c nv_0_rce_00092000097201482_v_02_d0001de0001.pdf. Acesso em: 03 set. 2018.

. CONSELHO DE SEGURANÇA NACIONAL. Diretriz de Segurança Interna, de 17 de março de 1970. Brasília, DF: Conselho de Segurança Nacional, 17 mar. 1970d. Disponível em: http://imagem.sian.an.gov.br/br_dfanbsb_n8/0/agr/avu/0013/br_dfanbsb_n8_0_agr_avu_0 013_d0001de0001.pdf. Acesso em: 03 set. 2018.

CONSELHO DE SEGURANÇA NACIONAL. Planejamento de Segurança Interna, de 29 de outubro de 1970. Brasília, DF: Conselho de Segurança Nacional, 29 out. 1970f. Disponível em: http://imagem.sian.an.gov.br/br_dfanbsb_n8/0/agr/avu/0013/br_dfanbsb_n8_0_agr_avu_0 013_d0001de0001.pdf. Acesso em: 03 set. 2018. 
Militarização das polícias e doutrina de segurança nacional no contexto do combate ao inimigo interno no Brasil (19691970)

. CONSELHO DE SEGURANÇA NACIONAL. Resolução, de 29 de outubro de 1970. Brasília, DF: Conselho de Segurança Nacional, 29 out. 1970g. Disponível em: http://imagem.sian.an.gov.br/br_dfanbsb_n8/0/agr/avu/0013/br_dfanbsb_n8_0_agr_avu_0 013_d0001de0001.pdf. Acesso em: 03 set. 2018.

Escola Superior de Guerra. Doutrina Básica. Rio de Janeiro: Imprimiu Gráfica e Editora Ltda., 1979. 352 p.

. MINISTÉRIO DA AERONÁUTICA. 4a Zona Aérea. Seminário de Segurança Interna: sugestões para integração dos órgãos de segurança interna - Relator Hely Lopes Meirelles, 13 mar. 1969a. São Paulo: Ministério da Aeronáutica, 1969. Disponível em: http://imagem.sian.an.gov.br/br_dfanbsb_vaz/br_an_bsb_vaz_019/br_an_bsb_vaz_019_02 1.pdf. Acesso em: 03 set. 2018.

. MINISTÉRIO DO EXÉRCITO. II Exército. Quartel General. OPERAÇÃO BANDEIRANTE. São Paulo: Ministério do Exército, 24 jun. 1969b. Disponível em: http://imagem.sian.an.gov.br/br_dfanbsb_v8/mic/gnc/aaa/70026616/br_dfanbsb_v8_mic_ gnc_aaa_70026616_d0002de0002.pdf. Acesso em: 03 set. 2018.

MINISTÉRIO DO EXÉRCITO. II Exército. Quartel General. Relatório Periódico de Informações. São Paulo: Ministério do Exército, 18 jan. 1971. Disponível em: http://imagem.sian.an.gov.br/br_dfanbsb_v8/mic/gnc/aaa/71033948/br_dfanbsb_v8_mic_ gnc_aaa_71033948_d0001de0001.pdf. Acesso em: 03 set. 2018.

. SERVIÇO NACIONAL DE INFORMAÇÕES. Agência Central. Informação no 306/969/SNI/AC (Relatório) - Assunto: FORÇA PÚBLICA DO ESTADO DE SÃO PAULO. Brasília: Serviço Nacional de Informações, 19 set. 1969e. Disponível em: http://imagem.sian.an.gov.br/br_dfanbsb_v8/mic/gnc/aaa/69022560/br_dfanbsb_v8_mic_ gnc_aaa_69022560_d0004de0006.pdf. Acesso em: 03 set. 2018.

BRASIL. SERVIÇO NACIONAL DE INFORMAÇÕES. Agência de São Paulo. BOLETIM INFORMATIVO № 12. São Paulo: Serviço Nacional de Informações, 15 jan. 1970a. Disponível em:

http://www.arquivoestado.sp.gov.br/uploads/acervo/textual/deops/boletins_SNI/Boletim_ 15_01_1970.pdf. Acesso em: 02 set. 2018.

- SERVIÇO NACIONAL DE INFORMAÇÕES. Agência de São Paulo. BOLETIM INFORMATIVO № 24. São Paulo: Serviço Nacional de Informações, 29 jan. 1970b. Disponível em:

http://www.arquivoestado.sp.gov.br/uploads/acervo/textual/deops/boletins_SNI/Boletim_ 29_01_1970.pdf. Acesso em: 02 set. 2018.

. SERVIÇO NACIONAL DE INFORMAÇÕES. Agência de São Paulo. BOLETIM INFORMATIVO № 27. São Paulo: Serviço Nacional de Informações, 02 fev. 1970c. Disponível em:

http://www.arquivoestado.sp.gov.br/uploads/acervo/textual/deops/boletins_SNI/Boletim_ 02_02_1970.pdf. Acesso em: 02 set. 2018.

. SERVIÇO NACIONAL DE INFORMAÇÕES. Agência de São Paulo. BOLETIM INFORMATIVO NNo 142. São Paulo: Serviço Nacional de Informações, 18 jun. 1970e. Disponível em: 
http://www.arquivoestado.sp.gov.br/uploads/acervo/textual/deops/boletins_SNI/Boletim_ 18_06_1970.pdf. Acesso em: 02 set. 2018.

. SERVIÇO NACIONAL DE INFORMAÇÕES. Agência de São Paulo. BOLETIM INFORMATIVO № 280, de 02 de dezembro de 1969. São Paulo: Serviço Nacional de Informações, 02 dez. 1969f. Disponível em: http://www.arquivoestado.sp.gov.br/uploads/acervo/textual/deops/boletins_SNI/Boletim_ 02_12_1969.pdf. Acesso em: 02 set. 2018.

. SERVIÇO NACIONAL DE INFORMAÇÕES. Agência Regional de São Paulo. Informação no 458/SNI/ASP/69 - Assunto: Operação Bandeirante. São Paulo: Serviço Nacional de Informações, 26 jun. 1969c. Disponível em: http://imagem.sian.an.gov.br/br_dfanbsb_v8/mic/gnc/aaa/70026616/br_dfanbsb_v8_mic_ gnc_aaa_70026616_d0002de0002.pdf. Acesso em: 03 set. 2018.

CARLOS, Juliana de Oliveira. A Anistia e a Luta pelos Direitos Humanos no Brasil. Cadernos AEL, v.13, n. 24/25, p. 169-205, 2008. Disponível em: https://www.ifch.unicamp.br/ojs/index.php/ael/article/view/2555/1965. Acesso em: 24 ago. 2018.

COMBLIN, Pe. J. A Ideologia da Segurança Nacional: O Poder Militar na América Latina. Tradução A. Veiga Fialho. Rio de Janeiro: Civilização Brasileira, 1978.

COMPARATO, Fábio Konder. Segurança Nacional. Novos Estudos, Cebrap, São Paulo, v.1, 1, p. 51-57, dez. 1981.

DAL RI Jr., Arno. O conceito de segurança nacional na doutrina jurídica brasileira: usos e representações do Estado Novo à Ditadura Militar brasileira (1935-1985). Revista de Direitos Fundamentais e Democracia, Curitiba, v. 14, n. 14, jul./dez. 2013, p. 525-543.

ESTUDO Sucinto n.o 06 SG-01/70, de 02 de fevereiro de 1970. Brasília, DF, 02 fev. 1970. Disponível em: http://imagem.sian.an.gov.br/br_rjanrio_cnv/0/rce/00092000097201482_v_02/br_rjanrio_c nv_0_rce_00092000097201482_v_02_d0001de0001.pdf. Acesso em: 03 set. 2018.

FON, Antônio Carlos. Tortura: A história da repressão política no Brasil. Revisão Dina de Deus. São Paulo: Global Editora e Distribuidora Ltda., 1979.

GOMES, Angela de Castro. A invenção do trabalhismo. 3. ed. Rio de Janeiro: Editora FGV, 2005. GUERRA, Maria Pia. Polícia e Ditadura: a arquitetura institucional da segurança pública de 1946 a 1988. Brasília: Ministério da Justiça e Cidadania, 2016.

Reformas institucionais: contribuições da justiça de transição e do direito e desenvolvimento. Revista Jurídica da UFERSA, Mossoró, v. 3, n. 5, 2019.

MARQUES, R. de P. Julgar o passado? Verdade histórica e verdade judicial na ADPF 153. Revista Jurídica da UFERSA, Mossoró, v. 2, n. 3, 2018.

MECCARELLI, Massimo. Regimes jurídicos de exceção e sistema penal: mudanças de paradigma entre Idade Moderna e Contemporânea. In: DAL RI Jr., Arno; SONTAG, Ricardo. História do Direito Penal entre medievo e modernidade. Belo Horizonte: Del Rey, 2011, p. 87 110. 
MEIRELLES, Hely Lopes. O poder de política, o desenvolvimento e a segurança nacional. Revista de Direito Administrativo, Rio de Janeiro, 125, jul. /set. 1976. p.1-14.

MEIRELLES, Hely Lopes. Minuta de Decreto-Lei: Dispõe sobre a segurança de estabelecimentos bancários e da outras providências. [S.I.: s.n.], [ca.1969]. Disponível em: http://imagem.sian.an.gov.br/br_dfanbsb_aaj/0/ipm/0591/br_dfanbsb_aaj_0_ipm_0591_d 0001de0001.pdf. Acesso em: 03 set. 2018.

MENDES, Ricardo Antonio Souza. Ditaduras civil-militares no Cone Sul e a Doutrina de Segurança Nacional - algumas considerações sobre a Historiografia. Revista Tempo e Argumento, Florianópolis, v. 5, n.10, jul./dez. 2013. p. 06 - 38.

MUNIZ, Jaqueline. A Crise de Identidade das Polícia Militares Brasileiras: Dilemas e Paradoxos da Formação Educacional. Security and Defense Studies Review, Vol. 1, Winter 2001. p. 177198.

NUNES, Diego. O percurso dos crimes políticos durante a Era Vargas (1935-1945): do Direito Penal político italiano ao Direito da Segurança Nacional brasileiro. 2010. 327p. Dissertação (Mestrado em Direito). Florianópolis: UFSC, 2010.

OLIVEIRA, Ramon Rebouças Nolasco de; CABRAL, Rafael Lamera Giesta. Comissão Nacional da Verdade no Brasil: o fio do relato e o direito à memória e à verdade. Revista Culturas Jurídicas, Niterói, v. 6, n. 13, 2019.

PINHEIRO, Paulo Sérgio. Polícia e Crise Política: o caso das polícias militares. In: BENEVIDES, Maria Vitoria et al. A Violência Brasileira. São Paulo: Brasiliense, 1982.

ROCHA, Alexandre Pereira da. A GRAMÁTICA DAS POLÍCIAS MILITARIZADAS: estudo comparado entre a Polícia Militar do Estado de São Paulo - Brasil e Carabineros - Chile, em regimes políticos autoritários e democráticos. 2013. 303f. (Doutorado em Ciências Sociais). Universidade de Brasília.

SÃO PAULO (Estado). Assembleia Legislativa do Estado de São Paulo. Comissão da Verdade do Estado de São Paulo "Rubens Paiva". Estruturas e Sistemas da Repressão. In: Relatório. São Paulo: 2015. 648 p. Disponível em: http://comissaodaverdade.al.sp.gov.br/relatorio/tomoi/downloads/I_Tomo_Parte_1_Completa.pdf. Acesso em: 15fev. 2018.

Secretaria de Segurança Pública. [Representação sugerindo as providências necessárias à prevenção e repressão dos assaltos a Bancos]. São Paulo, 29 maio. 1969a. Disponível em: http://imagem.sian.an.gov.br/br_dfanbsb_aaj/0/ipm/0591/br_dfanbsb_aaj_0_ipm_0591_d 0001de0001.pdf. Acesso em: 03 set. 2018.

Secretaria de Segurança Pública. Relatório Periódico Secreto n. 17/69. São Paulo, 16 jul. $1969 . \quad$ Disponível em: http://imagem.sian.an.gov.br/br_dfanbsb_aaj/0/ipm/0591/br_dfanbsb_aaj_0_ipm_0591_d 0001de0001.pdf. Acesso em: 03 set. 2018.

VAN ZYL, Paul. Promovendo a justiça transicional em sociedades pós-conflito. Revista Anistia Política e Justiça de Transição, n. 1 (jan./jun. 2009). Brasília: Ministério da Justiça, 2009. 